\title{
Growth, water consumption and basil production in the hydroponic system under salinity ${ }^{1}$
}

\author{
Jamille Ferreira dos Santos ${ }^{2 *}$ (D), Mauricio Antonio Coelho Filho ${ }^{3}$, Jailson Lopes Cruz ${ }^{3}$, \\ Tales Miler Soares ${ }^{2}$, Antonio Messias Lopes Cruz ${ }^{4}$
}

$10.1590 / 0034-737 X 201966010007$

\begin{abstract}
In irrigated crops, salinity is the main cause of the reduction of growth and productivity, with damage of the variability according to the sensitivity of the crop. The objective of this work was to evaluate the growth, water consumption and production of basil cv. Toscano Folha de Alface under saline stress, in different frequencies of recirculation of the nutritive solution and hydroponic systems. The experimental design was a completely randomized design, in a factorial scheme $3 \times 2+1$, where the first factor represents the concentrations of $\mathrm{NaCl}(0,40$ and $80 \mathrm{mmol} \mathrm{L}$ $\left.{ }^{1}\right)$ and the second factor the recirculation frequencies of the nutrient solution (4 or 6 hours) in a deep flow hydroponic system (DFT), and an additional treatment with nutrient solution in hydroponic laminar flow system (NFT). The water consumption, growth variables and phytomass production and growth rates were evaluated. Reducing the frequency of recirculation of the nutrient solution to six hours does not cause significant reductions in water consumption, growth, phytomass production and absolute growth rate of basil. The water consumption, growth, phytomass production and the absolute growth rate of basil reduced with the use of saline nutrient solution, 40 and $80 \mathrm{mmol} \mathrm{L}^{-1} \mathrm{NaCl}$. The choice of the DFT or NFT hydroponic system does not cause significant changes in the variables analyzed in basil, under the conditions studied.
\end{abstract}

Keywords: Deep flow technique; Laminar nutrient flow technique; Ocimum basilicum L.

${ }^{4}$ Instituto Federal de Educação, Ciência e Tecnologia, Santo Antônio de Jesus, Bahia, Brasil. messiascruz@ifba.edu.br

* Corresponding author: jamilleferreira08@gmail.com
} 


\section{INTRODUCTION}

Basil, from the family Lamiaceae, which is also known as alfavaca, alfavaca-doce and basilica, is a medicinal, spice and aromatic plant with significant importance in the world economic scenario (Luz et al., 2014).

In some regions of the Northeastern region of Brazil, basil crops are grown on a large scale, focused on the production of essential oil (Favorito et al., 2011). However, most of these localities present water shortages together with low and irregular rainfall precipitation, which leads to the search of techniques for more efficient use of water and also for the use of lower quality water (Silva et al., 2016), such as saline water.

Salinity is one of the main factors affecting basil production, since saline stress causes morphophysiological changes, such as nutritional imbalance, reduction in stomatal conductance, and lower proportions of transpiration and photosynthesis rates, resulting in decreased growth and production of these plants phytomass (Maia et al., 2017).

In view of the imminent need to use saline water for irrigation, one of the main challenges for researchers is related to the development or adaptation of management techniques that allow economic exploitation, even under conditions in which living with environmental adverse conditions, such as salinity, is unavoidable (Guimarães et al., 2013).

In this context, the hydroponic technique has become one of the technologies that allows the cultivation of plants in the presence of salts, because in this system the value of the matrix potential is close to zero, which allows a greater absorption of water and nutrients by the plants with lower energy expenditure than those grown in soil (Santos Junior et al., 2016). Different hydroponic techniques are used for the cultivation and production of the plants, however, the laminar nutrient flow (NFT) technique with high frequency recirculation of the nutrient solution and the deep flow technique (DFT) with a smaller recirculation interval are the most employed (Silva Filho, 2014). However, due to the high frequency of recirculation in the NFT system, there is dependence on the electric energy to drive the plants. Thus, the deep flow technique (DFT) is relevant for the rural communities of the Brazilian semi-arid region, where interruptions in the electric power supply are frequent (Santos Junior et al., 2015; Silva et al., 2016).

Studies indicate satisfactory results in the cultivation of plants in the DFT system, for tomato crops (Melo et al., 2014), of the coriander (Silva et al., 2016) and lettuce (Viana et al., 2018). However, some authors such as Bione et al. (2014) and Maia et al. (2017) observed that there is no compendium of consolidated information on the hydroponic cultivation of this culture under saline stress for basil.

Thus, it is necessary to conduct research that investigates the hydroponic cultivation of basil in adverse conditions such as salinity, as well as the use of hydroponic techniques that allow the reduction of the production costs of this crop, so as to allow farmers an alternative income in rural properties that have low availability of fresh water.

Therefore, this work was carried out with the objective of evaluating the growth, the water consumption and the production of basil cv. Toscano Folha de Alface under saline stress in different recirculation frequencies of nutrient solution and hydroponic systems.

\section{MATERIAL AND METHODS}

The research was developed from November to December 2015 at the Experimental Unit of the Nucleus of Water and Soil Engineering (NEAS) of the Federal University of Recôncavo da Bahia (UFRB), Cruz das Almas - BA, with geographic coordinates of $12^{\circ} 40$ ' 19 "south latitude, $39^{\circ} 06^{\prime} 23^{\prime \prime}$ west longitude and average altitude of $220 \mathrm{~m}$.

The $33 \mathrm{~m}$ long greenhouse with a simple arc (installed in the East / West direction) with $4 \mathrm{~m}$ of right foot, $7 \mathrm{~m}$ wide was covered with transparent plastic film (thickness 150 microns) and screens of $50 \%$ shading in the sides and as an internal undercoat, at right height. During the experiment the air temperature in the greenhouse oscillated between the minimum of $21.64{ }^{\circ} \mathrm{C}$ and the maximum $39.51^{\circ} \mathrm{C}$, with a mean of $27.35 \pm 2{ }^{\circ} \mathrm{C}$ and relative air humidity was $74 \%$.

The experimental design applied was completely randomized, in a factorial scheme $3 \times 2+1$, where the first factor represents the $\mathrm{NaCl}$ levels $\left(0,40\right.$ and $\left.80 \mathrm{mmol} \mathrm{L}^{-1}\right)$ added to the nutrient solution and the second factor the recirculation frequencies of the nutrient solution (4 or 6 hours) in a DFT hydroponic system, and an additional treatment with nutrient solution without $\mathrm{NaCl}$ in NFT system, for a total of 7 treatments and three replicates, in 21 experimental plots.

Seedlings of the cultivar Basil Toscano Folha de Alface were produced by means of sowing in coconut fiber allocated in plastic cups of $80 \mathrm{ml}$. After the emergence, the seedlings were irrigated with nutrient solution for leafy vegetables (Furlani, 1998), diluted to 50\%. At 21 days after emergence when the seedlings presented a completely expanded pair of leaves, they were transferred to the hydroponic system, where they remained for 30 days.

Deep flow hydroponics (DFT) systems were used, with zero slope and the laminar nutrient flow (NFT) systems with $4 \%$ slope in the crop channels. The hydroponic profiles were made in PVC pipes with $75 \mathrm{~mm}$ diameter, $6 \mathrm{~m}$ in length. Each hydroponic unit was connected to an electropump, which repressed the nutrient solution of a bobbin type reservoir with a capacity of $55 \mathrm{~L}$, to the hydroponic profile (experimental plots). Plants were grown at $0.40 \mathrm{~m}$ spacing between the tubes $\times 0.30 \mathrm{~m}$ between plants. 
The nutrient solution used followed the Furlani (1998) recommendation for leafy vegetables. In order to prepare the saline water that composed the nutrient solution of some treatments, different amounts (in grams) of $\mathrm{NaCl}$ were added to the water supply (CE - $\left.0.34 \mathrm{dS} \mathrm{m}^{-1}\right)$, so the $\mathrm{NaCl}$ concentrations used were 40 and $80 \mathrm{mmol} \mathrm{L}^{-1}$, corresponding to saline levels of 2,6 and $10 \mathrm{dS} \mathrm{m}^{-1}$, respectively, representing the sum of the nutrient solution (which is $2.0 \mathrm{dS} \mathrm{m}^{-1}$ ) with saline levels. Initial $\mathrm{pH}$ correction was not necessary.

The frequency of recirculation of the nutrient solution in the DFT system was as follows: interval of 4 hours - in the daytime period, recirculation at 6:00AM, 10:00AM, 2:00PM and 6:00PM and at night period-midnight; interval of 6 hours - in the daytime period, recirculation at 6:00AM, 12:00PM and 6:00PM and at night period, at midnight. In the NFT system, the recirculation frequency was applied in a 15 minute interval; in the diurnal period (6:00 AM 7:00 PM) the recirculation of the nutrient solution lasted 15 minutes at each 15 minute interval; and at night period, recirculation of the solution was performed twice (10:00PM and 03:00AM) and the system was switched on for $15 \mathrm{~min}$.

In both systems, control of the application of the solution was performed with the help of a digital timer. For the purposes of nutrient solution control, the electrical conductivity and $\mathrm{pH}$ of the solution were monitored every two days. The electrical conductivity of the solution was evaluated with a portable conductivity meter. The $\mathrm{pH}$ of the nutrient solution was monitored with the aid of a portable $\mathrm{pH}$ meter and its control was carried out whenever necessary with calcium hydroxide, in order to maintain the nutrient solution with $\mathrm{pH}$ in the range of 5.5 to 6.5 .

The recovery of evapotranspiration losses with the respective waters (supply or saline) characteristics of the treatments, as well as the evaluation of the water consumption of the plants were performed every three days, measuring the evapotranspiration volume (Equation 1).

$V E T C=\frac{(L f-L i) \times \pi \times D^{2} \times 10^{3}}{4 \times n \times \Delta t}$

Where: VETC is the evapotranspirated volume, L per plant per day; Lf is the final reading of the water level in the automatic filling tank, $\mathrm{m}$; $\mathrm{Li}$ is the initial reading of the water level in the automatic filling tank, $\mathrm{m}$; D is the internal diameter of the automatic filling tank, $\mathrm{m}$; $\ddot{\mathrm{AT}}$ is the time interval between readings, days; $n$ is the number of plants grown in the profile in the time interval ÄT.

For this, we used automatic filling tanks built with PVC pipe, connected by a hose to the reservoir. In this, a graduated ruler was added, fixed to a transparent hose, by which the volume of water consumed by the plants was determined (Soares et al., 2010).
The growth and yield data were collected at 18 and 30 days after transplanting (DAT). Two plants of each plot were selected for the evaluation of plant height $(\mathrm{cm})$, measured with a tape measure from the base to the apex, stem diameter $(\mathrm{mm})$ with the aid of a digital caliper and the number of leaves by direct counting manually. Also destructive evaluations were carried out and the root length (cm) was measured using a measuring tape, root volume with the aid of a graduated measuring cylinder in $\mathrm{mL}$, the leaf area $\left(\mathrm{cm}^{2}\right)$ by means of a portable meter (CID BioScience, Washington, United State of America, CI-202 model) and the dry matter mass of the plant organs ( $\mathrm{g}$ ) through a forced ventilation oven at $65^{\circ} \mathrm{C}$ for a period of $72 \mathrm{~h}$ and thereafter the mass of the dry matter was determined by weighing on a scale.

Absolute growth rates (AGR) and relative growth (RGR) were determined based on the dry matter mass of the plants and the net assimilation rate (NAR) by the leaf area of the plants. For the calculation of these variables, followed the methodology proposed by Peixoto et al. (2011), using the equations 2, 3 and 4:

$$
\begin{aligned}
& A G R=\frac{(W 2-W 1)}{(T 2-T 1)}\left(\mathrm{g} \mathrm{dia}^{-1}\right) \\
& R G R=\frac{(\ln W 2-\ln W 1)}{(T 2-T 1)}\left(\mathrm{g} \mathrm{g}^{-1} \mathrm{dia}^{-1}\right) \\
& N A R=\frac{(W 2-W 1)(\ln L 2-\ln L 1)}{(L 2-L 1)(T 2-T 1)}\left(\mathrm{g} \mathrm{cm}^{-2} \mathrm{dia}^{-1}\right)
\end{aligned}
$$

Where: W2 is the final dry mass in g; W1 is the Initial dry mass in $\mathrm{g}$; T2- T1 is the time interval between samplings; Neperian logarithm; L2 is the final leaf area; L1 is the initial leaf area.

The results were submitted to analysis of variance, where the significance of the treatments was evaluated by means of the $F$ test at the 0.05 probability level and the Tukey test. In order to evaluate the influence of hydroponic systems on basil production, the treatments in DFT with $0 \mathrm{mmol} \mathrm{L}^{-1} \mathrm{NaCl}$ and recirculation frequencies of 4 and 6 hours were compared with standard treatment NFT with $0 \mathrm{mmol} \mathrm{L}^{-1} \mathrm{NaCl}$ and recirculation frequency of 15 minutes, by the Dunnett test, at the 0.05 probhyability level.

Statistical analyzes were performed using ASSISTAT software (Silva \& Azevedo, 2016) and SAS 9.0 (Sas, 2011).

\section{RESULTS AND DISCUSSION}

\section{Water consumption}

There was no significant interaction effect of recirculation frequencies $\mathrm{x} \mathrm{NaCl}$ concentrations, as well as for isolated factor recirculation frequencies $(\mathrm{p}>0.05)$. The results corroborate with Silva et al. (2016), who also did 
not observe effects of recirculation frequencies of 0.25 hours, 2 hours, 4 hours and 8 hours when cultivating coriander in a DFT type hydroponic system until 20 days after transplanting.

There was a significant effect of $\mathrm{NaCl}$ concentration on water uptake by plants $(\mathrm{p}<0.05)$. The accumulated water consumption of basil gradually decreases with the increase of $\mathrm{NaCl}$ concentrations (Figure 1). For the concentration of 40 and $80 \mathrm{mmol} \mathrm{L}^{-1} \mathrm{NaCl}$, the reduction, relative to the control ( $\left.0 \mathrm{mmol} \mathrm{L}^{-1}\right)$, was, respectively, 18.2 and $36.1 \%$. These results are in agreement with several studies, in which reductions of the water consumption of the plants were observed as a result of the increased salinity of the irrigation water (Paulus et al., 2012; Rebouças et al., 2013; Silva et al. 2016).

This response is a consequence of the osmotic effect of the salts in the root environment of the plants. According to Alves et al. (2011), the osmotic effect of salinity on plant development may be due to the high concentrations of salts dissolved in the nutrient solution, which reduce its osmotic and water potential and, consequently, decrease the availability of water and nutrients to the plants.

\section{Basil growing}

As the reduction of the frequency of recirculation of the nutrient solution did not cause a decrease in the water consumption of the plants, it can be observed for the other variables analyzed in this study that this factor also did not present a significant effect. It was observed that there was a general trend of growth reduction with the increase of salinity at 18 DAT and with greater differences between treatments at 30 DAT, with the leaf area being the most affected by saline stress (Figure 2).

There was no significant effect of increasing $\mathrm{NaCl}$ concentration from 0 to $40 \mathrm{mmol} \mathrm{L}^{-1}$ for plant height ( $\mathrm{p}$ > 0.05 ) of basil, but this variable was negatively influenced

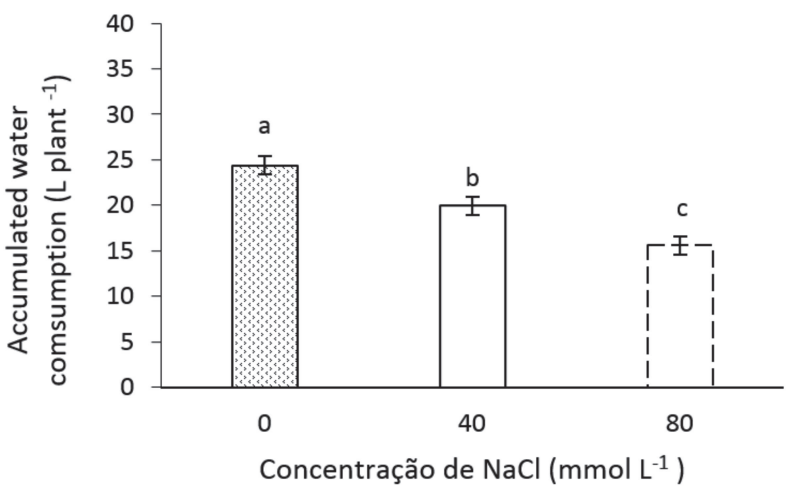

Figure 1: Accumulated water consumption (L.plant ${ }^{-1}$ ) of basil, at different concentrations of $\mathrm{NaCl}$, from six to 30 days after transplanting. The bars indicate the standard error of the averages. Means with the same letter do not differ, at the $5 \%$ probability level by the Tukey test. by the salinity of $80 \mathrm{mmol} \mathrm{L}^{-1}(\mathrm{p}<0.05)$, with decreases of $19.48 \%$, at 18 DAT. At 30 DAT, there was an effect of plant height $(\mathrm{p}<0.05)$ between all $\mathrm{NaCl}$ concentrations analyzed, thus a decrease of this variable of 8.47 and $29.0 \%$, respectively, was observed for the salinity of 40 and $80 \mathrm{mmol} \mathrm{L}^{-1}$, when compared to plants subjected to $0 \mathrm{mmol} \mathrm{L}{ }^{-1} \mathrm{NaCl}$ (Figure $2 \mathrm{~A}$ ).

There was no significant effect $(\mathrm{p}>0.05)$ between the concentrations of 0 and $40 \mathrm{mmol} \mathrm{L}^{-1} \mathrm{NaCl}$ for stem diameter, which was negatively influenced by the salinity of 80 mmol L-1 $(\mathrm{p}<0.05)$ with reductions of 39.7 and $36.1 \%$, respectively, at 18 and 30 DAT (Figure $2 \mathrm{~B}$ ).

The high concentrations of salts in the root zone cause alterations in the physiological responses of plants such as imbalance in the osmotic balance, disorganization of the membranes, inhibition in division and cellular expansion. This mismatch decreases plant growth, an event that can be manifested with reductions in plant height and in the diameter of the stems (Lima et al., 2015).

The increase in salinity levels impacted the root system of basil plants, reducing their length and volume at 18 and 30 DAT (Figures $2 \mathrm{C}$ and D).

There was no significant effect $(p>0.05)$ of the salt concentration increase from 0 to $40 \mathrm{mmol} \mathrm{L}^{-1}$ on root lengths which were severely affected at the salinity of 80 $\mathrm{mmol} \mathrm{L}^{-1}(\mathrm{p}<0.05)$, with reductions of $22.25 \%$ at $18 \mathrm{DAT}$. At 30 DAT, there were statistical significance $(\mathrm{p}<0.05)$ between all $\mathrm{NaCl}$ concentrations analyzed for this variable, thus comparing the plants submitted to $0 \mathrm{mmol} \mathrm{L}^{-1} \mathrm{NaCl}$ and those grown in the salinity of 40 and $80 \mathrm{mmol} \mathrm{L}^{-1}$, there was a decrease of 15.18 and $34.92 \%$, respectively (Figure 2 C).

There was a significant effect $(\mathrm{p}<0.05)$ between the $\mathrm{NaCl}$ concentrations in the root volumes, thus, when comparing the results obtained in the $\mathrm{NaCl}$ concentration of $0 \mathrm{mmol} \mathrm{L}^{-1}$ with those of 40 and $80 \mathrm{mmol} \mathrm{L}^{-1}$, there was a decrease of respectively, 33.33 and $41.75 \%$, at 18 DAT and 33.33 and $41.67 \%$ at 30 DAT, in the same order (Figure 2 D).

According to Cavalcante et al. (2010), high $\mathrm{Na}^{+}$and $\mathrm{Cl}^{-}$ concentrations in plant tissues lead to ionic toxicity due to changes in the $\mathrm{Na}^{+} / \mathrm{K}^{+}, \mathrm{Na}^{+} / \mathrm{Ca}^{++}$and $\mathrm{Cl}^{-} / \mathrm{NO}^{-3}$ ratios, which causes decreases in the growth of plants exposed to this stress. For Nascimento et al. (2011) one of the main damages caused by the excess of salts is the inhibition in the growth of the root system, due to the reduction of photosynthesis.

The number of leaves and leaf area of basil plants were also negatively affected by the salinity of the nutrient solution at 18 and 30 DAT (Figures $2 \mathrm{E}$ and F). There was no significant effect $(\mathrm{p}>0.05)$ between the $\mathrm{NaCl}$ concentrations of 40 and $80 \mathrm{mmol} \mathrm{L}^{-1}$ for the variable number of leaves at $18 \mathrm{DAT}$, however when comparing the salinity of 0 and $80 \mathrm{mmol} \mathrm{L}^{-1}$, there was a decrease of $28.12 \%$. At 30 DAT, it was observed that there was a gradual reduction 
of the number of leaves with increased saline stress ( $\mathrm{p}$ $<0.05$ ), so it was observed that in the concentrations of 40 and $80 \mathrm{mmol} \mathrm{L}^{-1} \mathrm{NaCl}$, there was a decrease of this variable of respectively 23.69 and $42.59 \%$ (Figure $2 \mathrm{E}$ ).

There were significant effects among all $\mathrm{NaCl}$ concentrations evaluated for leaf area of plants ( $p<0.05)$ of basil. Thus, when comparing the results obtained in the salinity of $0 \mathrm{mmol} \mathrm{L}^{-1}$ with that of 40 and $80 \mathrm{mmol} \mathrm{L}^{-1}$ of
$\mathrm{NaCl}$, reductions of 28.55 and $57.68 \%$, respectively, at 18 DAT and of 26.78 and $68.29 \%$ at 30 DAT (Figure 2 F).

The results indicate that the leaves are salinity sensitive organs, since the saline stress caused them to be reduced in size and number.

According to Sá et al. (2013), the reduction of leaf numbers due to the increase of saline stress may be related to the decrease of vertical stem growth, reducing the
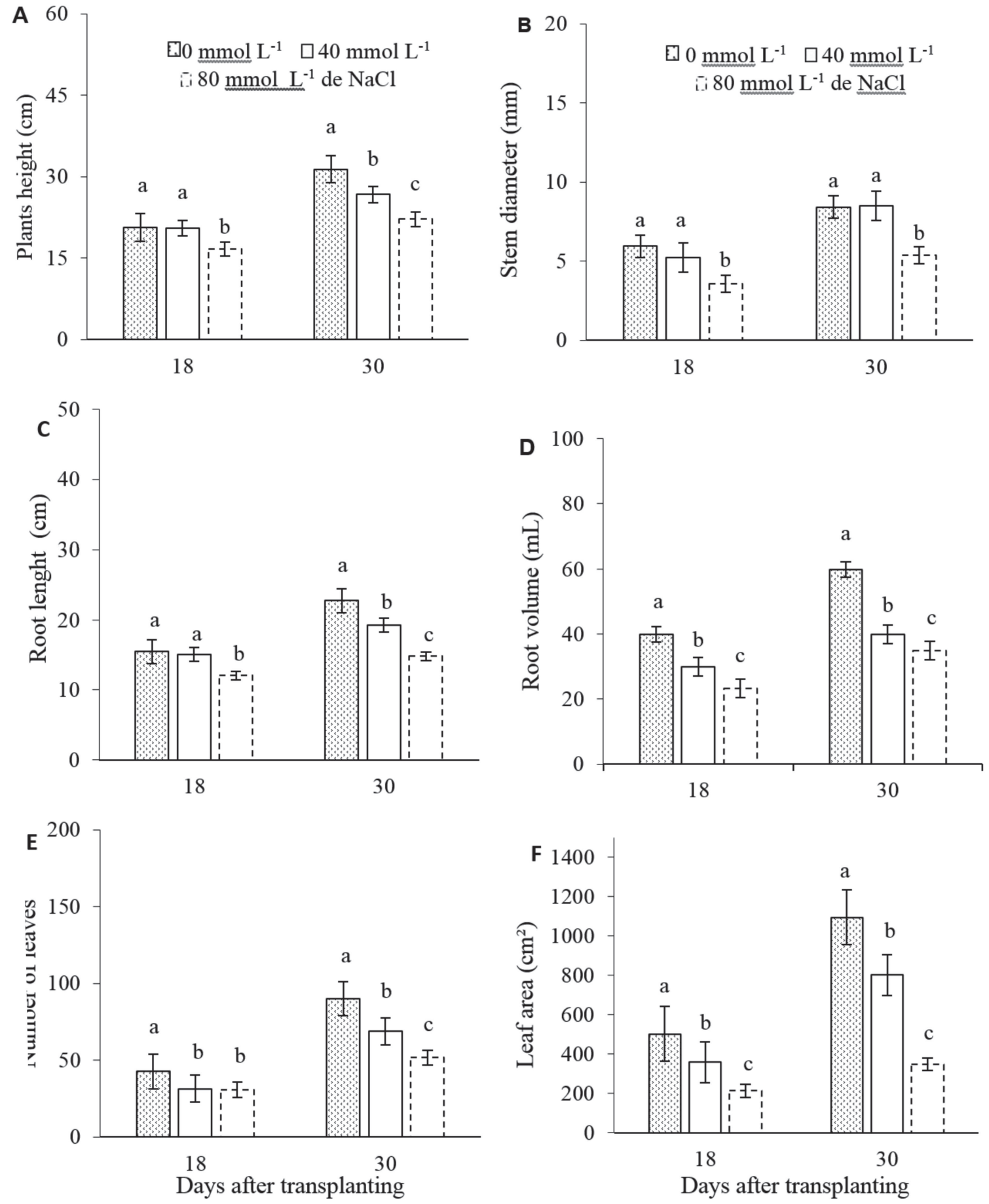

Figure 2: Plant height (A), stem diameter (B), root length (C), root volume (D), leaf number (E) and leaf area (F) of basil, under different concentrations of $\mathrm{NaCl}\left(0,40\right.$ and $\left.80 \mathrm{mmol} \mathrm{L}^{-1}\right)$ at 18 to 30 days after transplanting. The bars indicate the standard error of the averages. Means followed by the same letter do not differ, at the 5\% probability level by the Tukey test. 
emission of leaf buds, or even the death of buds due to the decrease of the absorption of water and/ or excess of toxic ions to the plant. For Prisco \& Gomes Filho (2010), the decrease of the leaf area of the plants under excess salts is a consequence of the reduction of the osmotic potential, and of the nutritional and hormonal imbalance, consequently, closure of leaf stomata and reduction in transpiration occur, resulting in in lower growth of these.
It is observed that there were similarities between the results of the basil growth variables, where all of these reduced their mean value with the increase of the $\mathrm{NaCl}$ concentration. This is possibly related to the excess absorption of $\mathrm{Na}^{+}$and $\mathrm{Cl}^{-}$ions found in the nutrient solution; these excess ions negatively modify the metabolic activities of the cells, and limit cell elongation, thereby reducing plant growth.
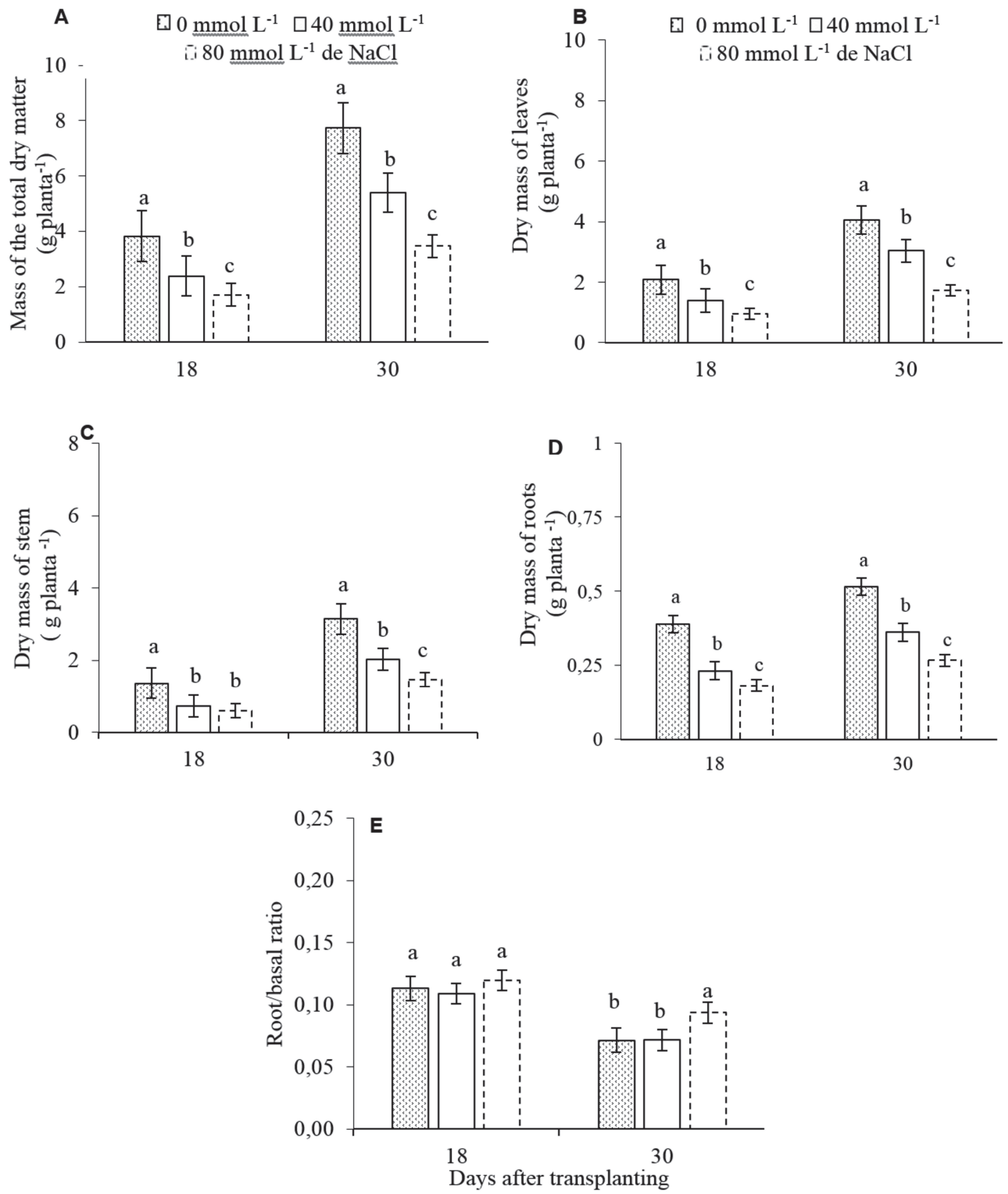

Figure 3: Mass of the total dry matter (a), leaves (b), stems (c), roots (d) and root / basal ratio of basil (e) under different $\mathrm{NaCl}$ concentrations $\left(0,40\right.$ and $\left.80 \mathrm{mmol} \mathrm{L}^{-1}\right)$ at 18 to 30 days after transplanting. The bars indicate the standard error of the averages. Means followed by the same letter do not differ, at the $5 \%$ probability level by the Tukey test. 


\section{Phytomass production of basil}

It was observed that leaves, stems and roots of basil were affected by applied saline stress, reducing the dry mass of leaves, stems and roots with increased salinity (Figures $3 \mathrm{~B}, \mathrm{C}$ and D). There was a gradual reduction of the mass of the total dry matter of the plants with the increase of the salinity ( $p<0.05)$, observing that between the lowest and the highest $\mathrm{NaCl}$ concentration there was a decrease of 53.93 and $64.47 \%$ respectively at 18 and 30 DAT (Figure $3 \mathrm{~A}$ ).

There were significant effects $(\mathrm{p}<0.05)$ between the concentrations of $\mathrm{NaCl}$ analyzed in the dry matter masses of the basil organ at 18 DAT and 30 DAT. Thus, when comparing the results obtained, at 18 DAT, at the concentration of $0 \mathrm{mmol} \mathrm{L}^{-1}$ with that of $40 \mathrm{mmol} \mathrm{L}^{-1} \mathrm{NaCl}$, reductions of $40.23,41.11$ and $40.36 \%$ were observed in the leaves, stems and roots, and between concentrations of 0 and $80 \mathrm{mmol} \mathrm{L}^{-1}$ the decreases in these organs were of the magnitude of $54.38,47.78$ and $53.21 \%$ in this sequence.

At 30 DAT, when the concentrations of 0 and $40 \mathrm{mmol}$ $\mathrm{L}^{-1} \mathrm{NaCl}$ were related, there was a decrease in the dry matter mass of leaves, stems and roots of basil, of 28.24, 44.34 and $29.70 \%$ respectively; in this same period, the leaves, stems and roots of the plants submitted to the salinity of $80 \mathrm{mmol} \mathrm{L}^{-1}$ of $\mathrm{NaCl}$ reduced $57.89,55.60$ and $57.86 \%$ when compared to those that were not exposed to the salinity (Figures 3 B, C and D).

The reduction of the dry matter mass of the plants under salt stress is due to the nutritional imbalance caused by the excess $\mathrm{Na}^{+}$and $\mathrm{Cl}^{+}$ions in the nutrient solution. The decrease in the number of leaves and leaf area, possibly influenced the photosynthetic process in plants submitted to concentrations of 40 and $80 \mathrm{mmol}$ $\mathrm{L}^{-1} \mathrm{NaCl}$, resulting in a lower carbon and energy gain for growth and, consequently, a lower accumulation of phytomass.

These results corroborate the work done by Menezes et al. (2018), which evaluated cultivar basil yield of the Alfavaca Basilicão in DFT under saline stress, observed a reduction of 58.0, 88.0 and $47.0 \%$ of the dry mass of leaves, stems and roots, respectively, when these plants were exposed to the salinity of $80 \mathrm{mmol} \mathrm{L}^{-1} \mathrm{NaCl}$.

Analyzing the results of the dry matter ratio of root dry matter/shoot mass, it can be observed that at $18 \mathrm{DAT}$ there was no significant effect of this ratio ( $p>0.05)$. This response is due to the similarity of the reduction of the mass of the dry matter in the organs of the plants during this period (Figures $3 \mathrm{~B}, \mathrm{C}$ and $\mathrm{D}$ ).

At 30 DAT, there was an effect of the concentration of $80 \mathrm{mmol} \mathrm{L}^{-1} \mathrm{NaCl}(\mathrm{p}<0.05)$ on the dry mass ratio of root dry matter/mass of the aerial part, this way the plants submitted to this salinity showed on average an increase of $48.27 \%$ relative to the control $\left(0 \mathrm{mmol} \mathrm{L}^{-1}\right)$. This can mean physiological response of the plant as a mechanism of survival to saline stress (Figure $3 \mathrm{E}$ ).

Increasing the root / shoot ratio in plants under salinity would be another mechanism of plant tolerance to stress, since the investment in the development of the root system may be a response to stress in some crops, due to the increase in the area of absorption of water and decrease of evapotranspiration area (Matos et al., 2013).

The results also suggest that the lower phytomass formation of the aerial part of the plants as a function of the $\mathrm{NaCl}$ concentration of the nutrient solution may be directly related to the leaf area (Figure $2 \mathrm{~F}$ ), since this was the growth variable most affected by the salinity (with a reduction of $68.29 \%$ ) and for being the source of photoassimilates formation.

\section{Growth rates}

There was no significant effect of $\mathrm{NaCl}$ concentrations on the relative growth rate $(p>0.05)$ as well as on the net assimilatory rate ( $p>0.05$ ) in the period from 18 to 30 DAT. However, there was a significant $(p<0.05)$ effect of the absolute growth rate (AGR), with significant reductions in $\mathrm{NaCl}$ concentrations of 40 and $80 \mathrm{mmol} \mathrm{L}^{-1}$, respectively, 35.0 and $70.24 \%$ in plant growth ( Figure 4).

This reduction of growth by salinity is the result of a set of factors that may be related to the deviation of the metabolic energy due to the adaptation of the plant under stress. This redirection of energy would be used in these, for the maintenance of the stability of the membranes, production of organic solutes and control in the transport and distribution of ions (Aragão et al., 2009).

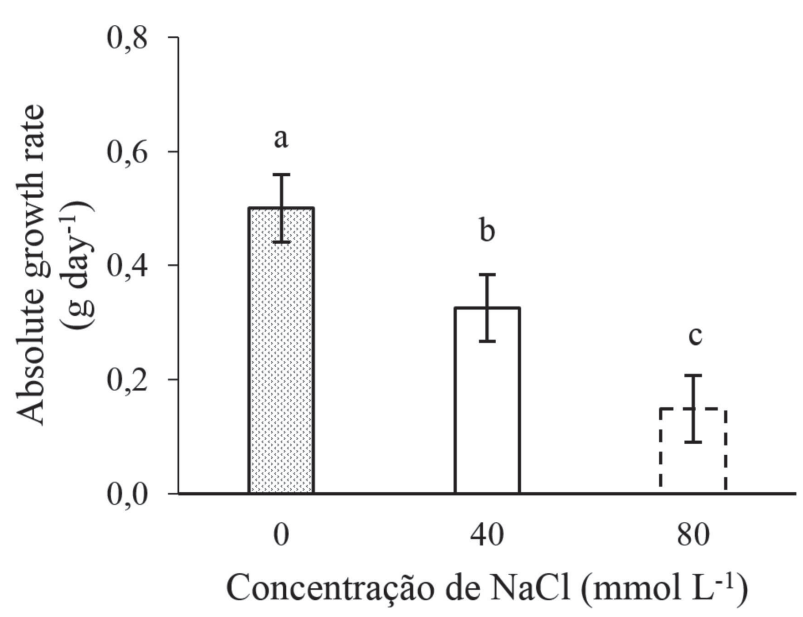

Figure 4: Absolute growth rate of basil, under different concentrations of $\mathrm{NaCl}\left(0,40\right.$ and $\left.80 \mathrm{mmol} \mathrm{L}^{-1}\right)$, in the period of 18-30 days after transplanting. Means followed by the same letter do not differ, at the $5 \%$ probability level by the Tukey test. 


\section{Estimates of contrasts of analyzed variables}

There were no significant effects between basil plants cultivated in the DFT type hydroponic system submitted to the recirculation frequency of 4 and 6 hours and those produced in NFT system with frequency of recirculation of the nutrient solution of 15 minutes ( $p>0.05$ ) for all variables of growth and production of phytomass, as well as for the absolute growth rate (Table 1).

This result allows the farmer to choose the system that provides greater savings in production costs, such as electric energy, through a greater recirculation interval of

Table 1: Estimates of contrasts between treatments in DFT versus NFT for the variables of water consumption, growth and phytomass production of basil plants.

\begin{tabular}{|c|c|c|}
\hline \multirow{3}{*}{ Variables } & \multicolumn{2}{|c|}{ Contrasts } \\
\hline & DFT (4 hours) & DFT (6 hours) \\
\hline & versus NFT & versus NFT \\
\hline & At $6-30$ DAT & \\
\hline \multirow[t]{2}{*}{$\mathrm{CH}$} & 0,471 ns & 0,663 ns \\
\hline & At 18 DAT & \\
\hline PA & $0,040^{\mathrm{ns}}$ & $0,060^{\mathrm{ns}}$ \\
\hline SD & $0,210^{\mathrm{ns}}$ & 0,307 ns \\
\hline NL & 3,000 ns & $3,667 \mathrm{~ns}$ \\
\hline LA & $2,610^{\mathrm{ns}}$ & 3,650 ns \\
\hline RL & 0,367 ns & 1,667 ns \\
\hline RV & 1,000 ns & $0,333^{\mathrm{ns}}$ \\
\hline DML & $0,180^{\mathrm{ns}}$ & 0,170 ns \\
\hline DMS & 0,040 ns & $0,300^{\mathrm{ns}}$ \\
\hline DMR & $0,070^{\mathrm{ns}}$ & $0,020^{\mathrm{ns}}$ \\
\hline \multirow[t]{2}{*}{ MTDM } & $0,423{ }^{\mathrm{ns}}$ & $0,497 \mathrm{~ns}$ \\
\hline & At 30 DAT & \\
\hline PA & $1,250 \mathrm{~ns}$ & 1,053 ns \\
\hline $\mathrm{SD}$ & 0,113 ns & $0,116^{\mathrm{ns}}$ \\
\hline NL & 3,333 ns & $4,100^{\mathrm{ns}}$ \\
\hline LA & 3,240 ns & 3,280 ns \\
\hline RL & $0,012^{\mathrm{ns}}$ & $0,018^{\mathrm{ns}}$ \\
\hline RV & 0,667 ns & 3,667 ns \\
\hline DML & $0,380^{\mathrm{ns}}$ & 0,109 ns \\
\hline DMS & 0,390 ns & 0,570 ns \\
\hline DMR & $0,030^{\mathrm{ns}}$ & 0,040 ns \\
\hline \multirow[t]{2}{*}{ MTDM } & $0,246^{\mathrm{ns}}$ & $0,312^{\mathrm{ns}}$ \\
\hline & 18 -30 DAT & \\
\hline AGR & 0,032 ns & $0,028{ }^{\mathrm{ns}}$ \\
\hline RGR & 0,027 ns & 0,022 ns \\
\hline NAR & 0,014 ns & 0,012 ns \\
\hline
\end{tabular}

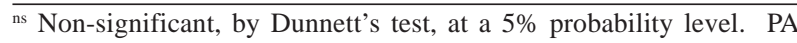
- plant height; SD - stem diameter; NL - number of leaves; LA- leaf area; RL- root lengths; RV- root volume; DML - dry mass of leaves; DMS - dry mass of stem; DMR- dry mass of root; MTDM - mass of the total dry matter; AGR- absolute growth rate; RGR- relative growth rate; NAR- net assimilation rate; DFT (4 hours) - treatment in DFT of $0 \mathrm{mmol} \mathrm{L}^{-1}$ de $\mathrm{NaCl}$ and frequency of 4 hours - DFT (6 hours) - treatment in DFT of $0 \mathrm{mmol} \mathrm{L}^{-1}$ de $\mathrm{NaCl}$ and frequency of 6 hours. DAT - days after transplanting the nutrient solution. These results agree with Walters \& Currey (2015), who did not find significant differences in basil growth in NFT and DFT systems under the same production conditions.

\section{CONCLUSIONS}

The reduction of the frequency of recirculation of the nutrient solution to six hours does not cause significant reductions in water consumption, growth, phytomass production and absolute growth rate of basil cv. Tuscan Lettuce Leaf.

Water consumption, growth, phytomass production and the absolute growth rate of basil reduced with the use of saline nutrient solution, 40 and $80 \mathrm{mmol} \mathrm{L}^{-1} \mathrm{NaCl}$.

The choice of the laminar nutrient flow (NFT) or deep flow technique (DFT) hydroponic system does not cause alterations in the growth and the production of phytomass, of basil cv. Tuscan Lettuce Leaf, under the conditions studied.

\section{REFERENCES}

Alves MS, Soares TM, Silva LT, Fernandes JP, Oliveira ML \& Paz VP (2011) Estratégias de uso de água salobra na produção de alface em hidroponia NFT. Revista Brasileira de Engenharia Agrícola e Ambiental, 15:491-498.

Aragão CA, Santos JS, Queiroz SOP \& França B (2009) Avaliação de cultivares de melão sob condições de estresse salino. Revista Caatinga, 22:161-169.

Bione MAA, Paz VPS, Silva F, Ribas RF \& Soares TM (2014) Growth and production of basil in NFT hydroponic system under salinity. Revista Brasileira de Engenharia Agrícola e Ambiental, 18:1228-1234.

Cavalcante LF, Cordeiro JC, Nascimento JAM, Cavalcante IHC \& Dias TJ (2010) Fontes e níveis da salinidade da água na formação de mudas de mamoeiro cv. Semina: Ciências Agrárias, 31:1281-1290.

Favorito PA, Echer MM, Offemann LC, Schlindwein MD, Colombare LF, Schineider RP \& Hachmann TL (2011) Características produtivas do manjericão (Ocimum basilicum L.) em função do espaçamento entre plantas e entre linhas. Revista Brasileira de Plantas Medicinais, 13:582-586.

Furlani PR (1998) Instruções para cultivo de hortaliças de folhas pela técnica de hidroponia NFT. Campina, Instituto Agronômico. 30 p. (Boletim técnico 168).

Guimarães IP, Oliveira FN, Vieira FER \& Torres SB (2013) Efeito da salinidade da água de irrigação na emergência e crescimento inicial de plântulas de mulungu. Revista Brasileira de Ciências Agrárias, 08:137-142.

Lima AL, Oliveira FA, Alves RC, Linhares PSF, Medeiros AMA \& Bezerra FMS (2015) Tolerância da berinjela à água de irrigação. Revista Agroambiente, 09:27-34.

Luz JM, Resende RF, Silva SM, Santana DG, Camilo JS, Blank AF \& Haber LL (2014) Produção de óleo essencial de Ocimum basilicum L. em diferentes épocas, sistemas de cultivo e adubações. Boletim Latinoamericano e Caribe de Plantas Medicinais e Aromáticas, 13:69-80. 
Maia SSS, Silva RCP, Oliveira FA, Silva OMP, Silva AC \& Candido WS (2017) Responses of basil cultivars to irrigation water salinity. Revista Brasileira de Engenharia Agrícola e Ambiental, 21:44-49

Matos FS, Rocha EC, Cruvinel CKL, Ribeiro RA, Ribeiro RP \& Ticono CF (2013) Desenvolvimento de mudas de pinhão-manso irrigadas com água salina. Revista Brasileira de Ciências do Solo, 37:947-954.

Melo NC, Souza LC, Gomes RF, Oliveira Neto CF \& Costa DLP (2014) Cultivo de tomate (Solanum lycopersicum) hidropônico sob diferentes níveis de fósforo e potássio em solução nutritiva. Revista Agroecossistemas, 06:10-16.

Menezes RV, Azevedo Neto AD, Gheyi HR, Cova AMW \& Silva HHB (2017) Tolerance of basil genotypes to salinity. Journal of Agricultural Science, 09:283-295.

Nascimento JA, Cavalcante LF, Santos PDD, Silva SAD, Vieira MD S \& Oliveira APD (2011) Efeito da utilização de biofertilizante bovino na produção de mudas de pimentão irrigadas com água salina. Revista Brasileira de Ciências Agrárias, 06:258-264.

Paulus D, Paulus E, Nava GA \& Moura CA (2012) Crescimento, consumo hídrico e composição mineral de alface cultivada em hidroponia com águas salinas. Ceres, 59:110-117.

Peixoto CP, Cruz TV \& Peixoto MFS (2011) Análise quantitativa do crescimento de plantas: Conceitos e Prática. Enciclopédia Biosfera, 07:51-76.

Prisco JT \& Gomes Filho E (2010) Fisiologia e bioquímica do estresse salino em plantas. In: Gheyi HR, Dias NS \& Lacerda CF (Eds.) Manejo da salinidade na agricultura: Estudos básicos e aplicados. Fortaleza, INCT. p. 147-164.

Rebouças JRL, Ferreira Neto M, Dias NS, Souza Neto ON, Diniz AA \& Lira RB (2013) Cultivo hidropônico de coentro com uso de rejeito salino. Irriga, 18:624-634.

Sá FVS, Brito MEB, Melo AS, Neto PA, Fernandes PD \& Ferreira IB (2013) Produção de mudas de mamoeiro irrigadas com água salina. Revista Brasileira de Engenharia Agrícola e Ambiental, 17:1047-1054.
Santos Júnior JA, Gheyi HR, Cavalcante AR, Medeiros SS, Dias NS \& Santos DB (2015) Water use efficiency of coriander produced in a low-cost hydroponic system. Revista Brasileira de Engenharia Agrícola e Ambiental, 19:1152-1158.

Santos Júnior JÁ, Gheyi HR, Guedes Filho DH, Soares FAL \& Silva ND (2016) Eficiência do uso da água para girassol cultivado em sistema hidropônico sob estresse salino. Engenharia Agricola, $33: 342-350$.

Sas (2011) Statistical Analysis System, for Microsoft Windows. Version 9.3. Cary, SAS Institute, 536p.

Silva FAZ \& Azevedo CAV (2016) The Assistat Software Version 7.7 and its use in the analysis of experimental data. African Journal of Agricultural Research, 11:3733-3740.

Silva MG, Soares TM, Gheyi HR; Oliveira IS, Silva Filho JÁ \& Carmo FF (2016) Frequency of recirculation of nutrient solution in hydroponic cultivation of coriander with brackish water. Revista Brasileira de Engenharia Agrícola e Ambiental, 20:447454.

Silva Filho JA (2014) Produção e consumo hídrico da hortelã utilizando águas salobras nos sistemas hidropônicos NFT e Floating. Dissertação de Mestrado. Universidade Federal do Recôncavo da Bahia, Cruz das Almas. 123p.

Soares TM, Duarte SN, Silva EFF \& Jorge CA (2010) Combinação de águas doce e salobra para produção de alface hidropônica. Revista Brasileira de Engenharia Agrícola e Ambiental, 14:705714.

Viana PC, Freitas FTO, Silva ND, Soares TM \& Paz MGF (2018) Estatística multivariada como ferramenta descritiva na análise sensorial de alface hidropônica produzida com águas salobras. Revista Brasileira de Agricultura Irrigada, 12:2725-2730.

Walters KJ \& Currey CJ (2015) Hydroponic greenhouse basil production: Comparing systems and cultivars. HortTechnology, 25:645-650. 